\title{
Integration of Terrestrial Laser Scanning and UAS Photogrammetry in Geological Studies: Examples from Croatia
}

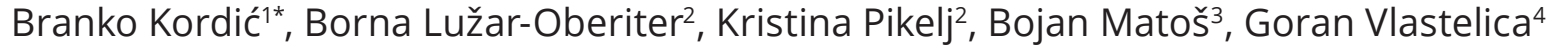 \\ 1 Department of Geomatics, Faculty of Geodesy, University of Zagreb, Kačićeva 26, 10000 Zagreb, Croatia \\ 2 Department of Geology, Faculty of Science, University of Zagreb, Horvatovac 102a, 10000 Zagreb, Croatia \\ ${ }^{3}$ Department of Geology and Geological Engineering, Faculty of Mining, Geology and Petroleum Engineering, University of Zagreb, \\ Pierottijeva 6, 10000 Zagreb, Croatia \\ ${ }^{4}$ Faculty of Civil Engineering, Architecture and Geodesy, University of Split, Matice hrvatske 15, 21000 Split, Croatia \\ * Corresponding author, e-mail: bkordic1701@gmail.com
}

Received: 02 June 2019, Accepted: 12 September 2019, Published online: 07 October 2019

\begin{abstract}
Terrestrial laser scanning (TLS) in combination with Unmanned Aircraft System (UAS) and modern computer based photogrammetry is currently the best approach for the acquisition of high-resolution 3D spatial information. Highly realistic 3D spatial data sets are becoming the basis for detailed geological studies, providing a multidisciplinary approach in the study and research of both underground and above ground sites. To emphasize the variety of possible implementations of these state-of-the-art methodologies, four characteristic and yet quite different case studies are presented where such geodetic techniques are successfully employed. The presented case studies demonstrate that TLS and UAS photogrammetry, as non-contact surveying methods, are able to reduce survey time and total project costs. As added value, they provide high-resolution data that can be analyzed in a virtual environment from a sedimentological or structural aspect. Stored digital documentation also allows future multi-temporal spatial data comparison at any timeframe and scale, thus enhancing any target geological data gathering and analyses at the studied sites.
\end{abstract}

Keywords

Terrestrial Laser Scanning (TLS), Unmanned Aircraft System (UAS), photogrammetry, 3D virtual model building, virtual outcrop

\section{Introduction}

Description of the three-dimensional properties of natural objects and processing them in a digital form has become common in many areas of human activity, particularly in various areas of scientific research. Continuous advances in computer technology in the last two decades lead to a growing demand for high quality and detailed spatial data in many geoscience disciplines. In order to meet these new spatial data requirements, it became necessary to develop practical applications that utilize state-of-the-art geodetic instruments and specialized computer software solutions. Therefore, to synthesize variety of successful geological and geotechnical applications four case studies are selected that implement two relatively new geodetic methods: terrestrial laser scanning (TLS) and Unmanned Aircraft System (UAS) photogrammetry.

Implementation of TLS and UAS photogrammetry in geosciences has proven itself as a valuable tool for creating virtual $3 \mathrm{D}$ spatial data that enhances modeling and analysis. The application of TLS was initially extensively used in the private sector for various commercial purposes (piping networks in industrial environments, civil engineering, etc.), however, during the last decade academic and research institutions started to use TLS for variety of applications [1]. From seismic event change detection [2], structural and sedimentary studies [3-5], archeological and paleontological investigations [6-9] to geological engineering such as virtual outcrop analyses, cliff sections modeling, landslide body models [10-14] and many others.

These very recent multipurpose applications of TLS and UAS photogrammetry were linked to major advances in geodesy, computational speed process, available software, and digital imaging devices that have allowed even non-specialists to produce 3D digital outcrop models [15].

In Croatia, there is an increasing trend of interdisciplinary cooperation between geological and geodetic studies that often correlate with field studies i.e., collecting of 
2D and 3D geological data that are used both in scientific research and in practical application, which commonly address geotechnical, hydrogeological and civil engineering issues [16-21].

Although basic field tools (e.g. field notebook, geological map, compass, logs, profiles, etc.) remain essential to field geologists, the addition of TLS, photogrammetry and other GIS technologies for 3D modeling of geological sites have a great potential for augmenting and significantly optimizing "classical" observation and analysis of geological data. Cross-correlation and integration of the photogrammetry and TLS data in the geology and other geosciences provide a revolution in geological studies. They provide an accurate method for the precise mapping and interpretation of the geological structures and features that may significantly improve knowledge of existing geological models and features, and understanding of their evolution trough time [22, 23].

Principal objective of this contribution is to elaborate the practical benefits of approaches, which incorporate geodetic methods, i.e., TLS and/or photogrammetry data in order to construct 3D virtual outcrop models for specific geological studies. Data was acquired and processed at four pilot sites in Croatia: Cerovačke Caves (Nature Park Velebit), Bizek quarry (Mt. Medvednica), Solaris dinosaur tracksite (Istria), and Duilovo flysch cliff (City of Split). Virtual 3D models were used for basic identification of discontinuities, lithological units, dinosaur tracksite morphometry as well as cliff face erosion and occurrence of landslides.

\section{Methods}

\subsection{Laser scanning system}

The LiDAR (Light Detection and Ranging) technology has a purpose to generate photorealistic virtual model that can be geometrically measured and interpreted [24]. Though the laser scanner refers to instruments that work on different principles, in different environments and levels of accuracy, they all provide a three-dimensional spatial data characterized by a large number of data points with spatial coordinates. The principle of laser scanning is similar to total station. Obtained three-dimensional coordinate points are based on the distance provided by laser beam and incident angle. In addition to the spatial coordinates, each point contains information on the intensity dependent on the reflective properties of the object [25]. If a calibrated internal or external camera is used with a laser scanner, then an RGB attribute can be added for each point [26].
In this study spatial data were collected with Faro Focus and Optech terrestrial laser scanners (Fig. 1). Faro Focus 3D X 130 HDR is the panoramic phase shift based distance measurement three dimensional laser scanner used for data acquisition in Cerovačke Caves, Solaris dinosaur tracksite and Bizek quarry case studies. Scanner is equipped with HDR RGB 70 megapixel camera, dual axis compensator, magnetic compass, electronic barometer, single frequency GNSS receiver and WLAN for remote control. In the same time, Optech ILRIS-3D is the time of flight (TOF) based terrestrial laser scanner capable for long distance measurements that was used at the Duilovo flysch cliff study location. It is equipped with 3.1 megapixel camera and WLAN, while high resolution camera and GNSS receiver can be mounted with an additional kit. The generalized terrestrial laser scanning workflow used here is presented in the Fig. 2.

Usually, field survey is performed from a sufficient number of stations for detail coverage of the object. One of the principal advantage of laser scanning is fast acquisition of spatial data. This obviously reduces the time required for field measurements and thus reduces the project costs. Fieldwork is followed by data processing in the office. First step is registration of local oriented point clouds from each station into common coordinate system. After registration, it is necessary to georeference the unique locally oriented point cloud into an external coordinate system. Thus, data collected by laser scanning can be combined with other geospatial data. Point cloud filtering is also performed in the process of data processing. Filtering is usually performed by semi-automatic methods; however, manual process of point cloud is in most cases an indispensable part of data processing. Data filtering can be

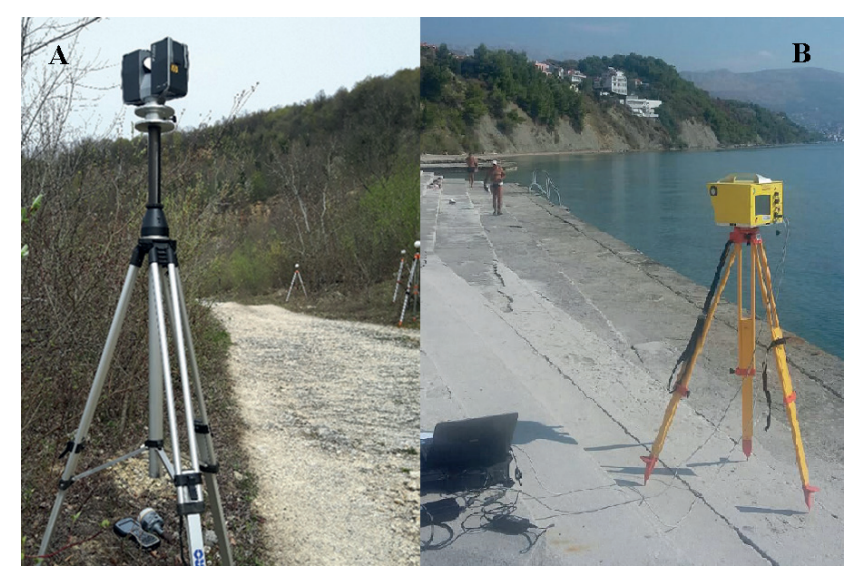

Fig. 1 a) Faro Focus X 130 terrestrial laser scanner at Bizek quarry; b) Optech ILRIS 3D scanning coastal cliff at Duilovo 


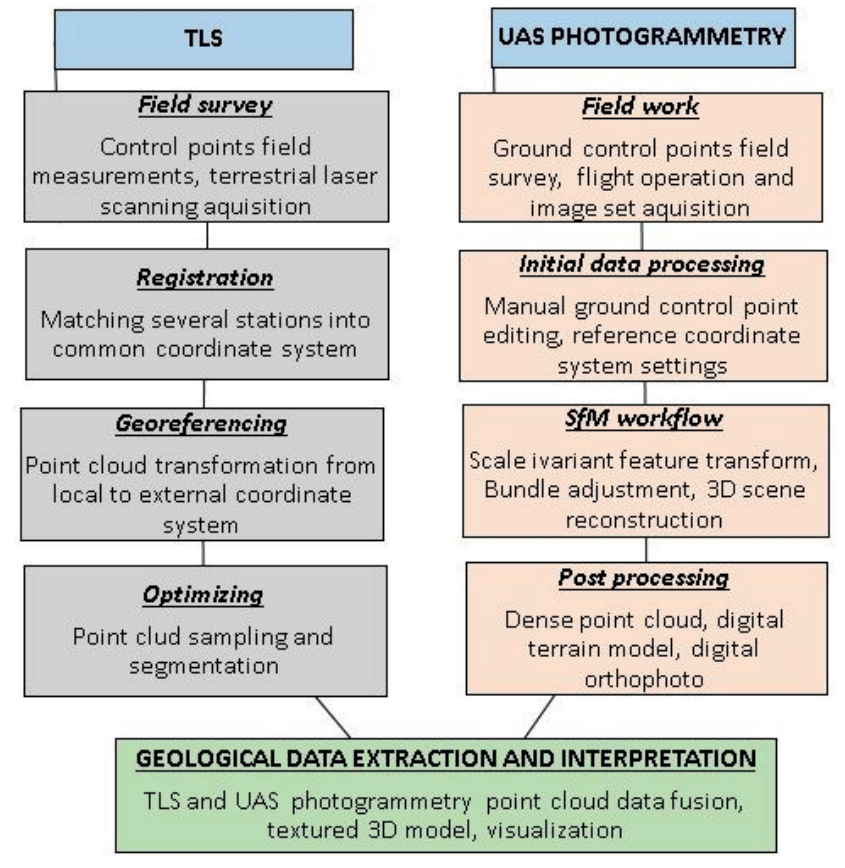

Fig. 2 Generalized TLS an UAS photogrammetry workflow

performed in several steps during data processing. Finally, the point cloud is optimized depending on the end product or the further data usage.

\subsection{UAS photogrammetry}

In recent years, Unmanned Aircraft System (UAS) photogrammetry as spatial data collection method was developed. This very popular topic has found its application in geodesy [27], mostly because a large number of modern and relatively low-cost UASs are available on the market. The products generated from UAS photogrammetry usually consider dataset such as point clouds, high-resolution digital surface models, high resolution digital orthophoto, photorealistic 3D models and visualizations [28]. Used in interdisciplinary studies, these datasets resembles high-resolution spatial data acquired by micro technology, IT systems as well as Structure from Motion (SfM) technique for photogrammetric data processing transferring topographic survey and mapping to a virtual reality in the office in a significantly reduced time period. In this study rotary wing UAS was used i.e., custom made hexacopter multirotor with possibility of installation of different camera and DJI Phantom 4 for spatial data collection at the Bizek quarry and Duilovo cliff locations respectively (Fig. 3). The generalized workflow of UAS photogrammetry that implements SfM algorithm for 3D scene reconstruction is presented in Fig. 2.

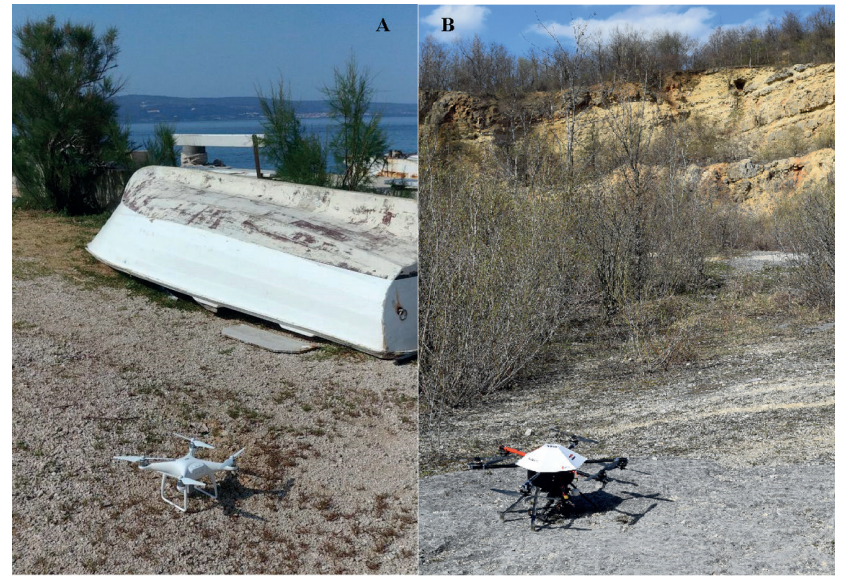

Fig. 3 a) DJI Phantom 4 ready for Duilovo. cliff erosion monitoring mission and b) Hexacopter multirotor at the Bizek quarry

As with any geodetic method field measurements are an indispensable part of the process. The field survey consists of collecting images during predefined planned missions using the UAS. If the UAS is not equipped with GNSS/ INS for Direct Sensor Orientation (DiSO) then Ground Control Points (GCPs) have to be set at the field before flight operations. Integrated Sensor Orientation (ISO) will be performed in post processing based on determined coordinates of GCPs along with initial position and attitude of camera sensor. Initial data processing at the office consist of assignment of coordinates of images center (if coordinate data is available), eventually manual assignment of GCPs at the images and initial setup of coordinate systems. SfM workflow consist of several steps. First step is an automatic identification and feature matching in multiple overlapping images using SIFT (Scale Invariant Feature Transform) object recognition system. Then matching feature points along with accurate or approximate image position and orientation are used in bundle block adjustment procedure. Based on 3D object reconstruction dense point cloud can be generated as well as high resolution digital surface model, orthophoto and image based textured 3D model.

\section{Case studies}

\subsection{The Cerovačke caves (Nature park Velebit)}

The first investigated case area in this study were Cerovačke Caves that are karstic cave system phenomena in the southeastern part of the Mt. Velebit within the Nature Park (NP) Velebit. The Cerovačke Caves were discovered in the 1913 during the Zagreb-Split railway construction in the vicinity of town Gračac (Fig. 4), along the northern slopes of the mountain massive Crnopac [29-31]. 
Composed from Upper, Middle and Lower Cerovačke Caves system, already in the 1951 the Upper and Lower Cerovačke Caves were prepared for visitor tours. Through the history of almost seventy years of touristic visiting in the this area of Mt. Velebit every year additional tenths of meters of trails were put in order, ending with 608 meters in total [29-31]. The relative small entrance in the Cerovačke Caves system (Fig. 5) is positioned along the northern slopes of the mountain massive Crnopac at the $624 \mathrm{~m}$ a.s.l. The cave system is striking toward SE, however after $160 \mathrm{~m}$ it turns toward $\mathrm{W}$ being cca. $750 \mathrm{~m}$ long. At the end of cave system there is vertical drop of $23 \mathrm{~m}$, finishing with several galleries and channels [29, 30]. Beside geological and geomorphological importance, Cerovačke Caves are one of a few archeological (Iliric and

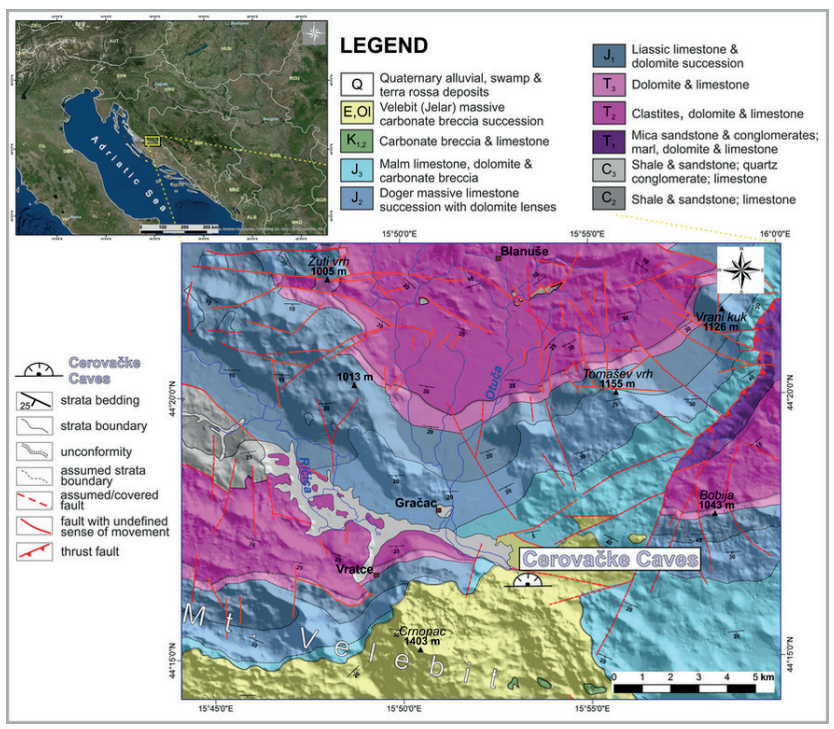

Fig. 4 Location of the Cerovačke Caves in the SE area of Mt. Velebit (index map in the left corner). The Cerovačke Caves are formed within Eocene-Oligocene carbonate breccias composed of Jurassic, Cretaceous and Paleogene fragments [34, 35]

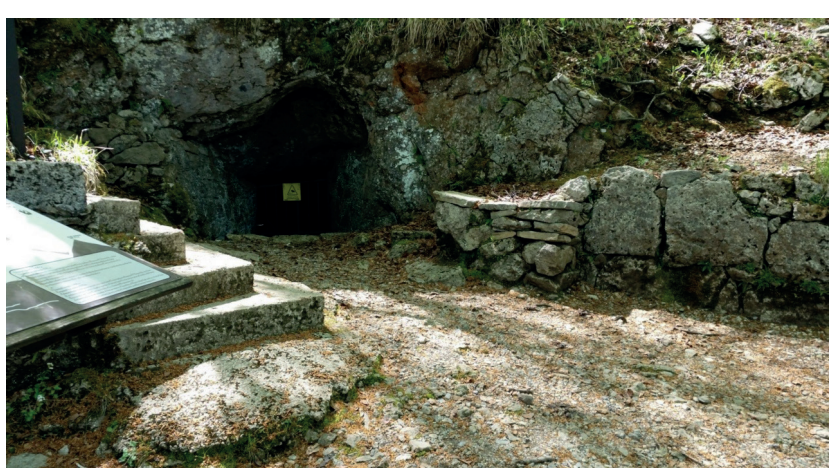

Fig. 5 Entrance in the Lower Cerovačke Caves system. The entrance is positioned at the base of northern slopes of the Crnopac Mt. and is a few meter scale
Celtic cultures) and paleontological sites in the Mt. Velebit area that document continuous inhabitance and human activity in the wider area from iron age onwards [31, 32]. In respect to that, taking into account possibility of new scientific findings in the Cerovačke Caves system as well as its potential contribution to touristic offer in this work our research objectives were to collect and process data of 3D terrestrial laser scanning of the Cerovačke Caves. Particularly, the collected data were used for building 3D visualization of Lower Cerovačke Cave.

\subsubsection{Geological settings}

The Cerovačke Caves system as a part of mountain massive Crnopac (Fig. 4) i.e., Mt. Velebit is formed within massive polymictic Paleogene carbonate breccia, Velebit (i.e., Jelar) breccia [33, 34]. Carbonate breccia are composed of limestone and dolomite fragments that are Jurassic, Cretaceous and Paleogene age. Though the origin of breccia is not completely understood, it is considered that they may be associated both to tectonic uplift and formation of Mt. Velebit in Eocene and Oligocene, as well as weathering processes associated to uplifted Mesozoic and Paleogene successions [33-36]. In the area of the Cerovačke Caves fault systems are dominantly NW, E and NE striking features (Fig. 4) with subparallel fracture systems. Clast size within breccia is extremely variable, depending on a degree of tectonization, angular to subangular, from several $\mathrm{mm}$ to several $\mathrm{dm}$ to even metersizes. Velebit breccia are in most cases in disconformable or tectonic contact with Upper Jurassic and Lower Cretaceous limestones, reaching the total thickness of cca. 600 m [33-35]. (Fig. 4). In the Cerovačke Caves system, most of the breccia walls are covered with speleothems (Fig. 6). Cave channels, galleries and other karstic features in overall follow geometry of penetrative fracture systems in the area that are subparallel to existing fault systems.

Hydrogeologically, breccia bedrock of the Cerovačke Caves system is characterized by dense fracture system that is strongly corroded and chemically weathered. The Caves system is generally above phreatic zone, however several intermittent watercourses within cave system transport and deposit fine grained sediments i.e. clays, whereas very slow water circulation at the cave bottom, walls and ceiling yield numerous types of speleothems [33, 34] (Fig. 6). The Quaternary evolution of Cerovačke Caves system is associated with interchange of glacial and interglacial stages in the area of Gračac polje (Fig. 4) that conveyed periodic presence of perennial and intermittent courses in the area, 


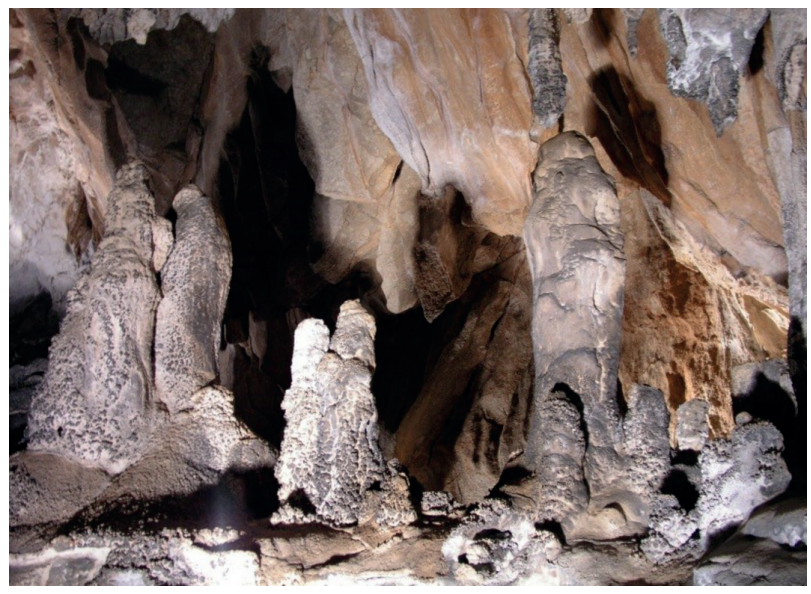

Fig. 6 Speleothems in the Lower Cerovačke Caves

which at SE margin of the Gračac polje ended with sinking stream system. In general, dynamic climate changes in Quaternary in combination with neotectonic activity trough Neogene and Quaternary resulted in complex cave channel geometry at the three depth levels, i.e., Upper, Middle and Lower Cerovačke Caves system [36].

\subsubsection{Methodology and model building procedure}

In 2017, through several data acquisition campaigns the Lower Cerovačke Cave systems were recorded and geodetically measured using TLS. The geodetic measurements involved definition of geodetic positon using GNSS Topcon HiPer SR and total stations TOPCON GTS 105N. The geodetic positioning involved usage of geodetic network outside and within cave system, whereas measurements and temporary stabilization was performed using official Croatian coordinate system HTRS96/TM [34]. The geodetic network outside cave systems involved application of GNSS, whereas absolute positioning involved application of CROPOS system. CROPOS is state network of referent GNSS station within territory of Croatia that enhance quality of positioning and navigation [37] with a $2 \mathrm{~cm}$ horizontal and $4 \mathrm{~cm}$ vertical accuracy. Geodetic measurements and terrestrial laser scanning of the Lower Cervačke Caves involved FARO Focus 3D X130 (Fig. 1). The TLS data were processed using Faro Scene version 5.5 software. This software is specially designed for Faro Focus 3D laser scanner enabling automatic object recognition, scan registration and georeferencing.

Additionally, collected laser scanning data were composed of 64 datasets, which were down sampled to subset of $1 \mathrm{~cm}$ horizontal and vertical resolution, with minimal horizontal and vertical deviations of $2-3 \mathrm{~cm}$. The number of cca. 43 million of point cloud data per scan

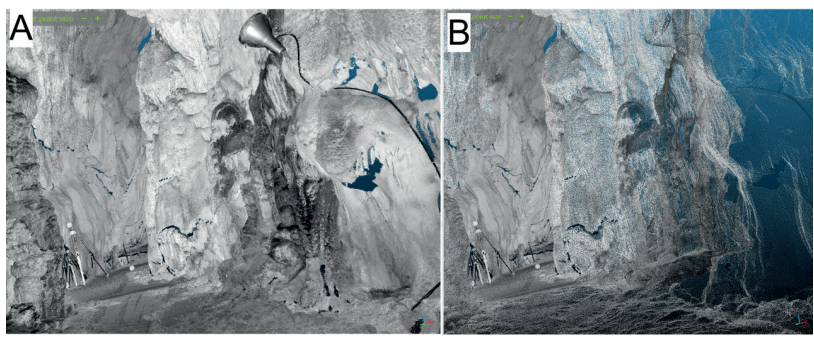

Fig. 7 a) Initial resolution of point cloud with 43 million points; b) Down sampled point cloud composed of 300000 points and removed undesired objects

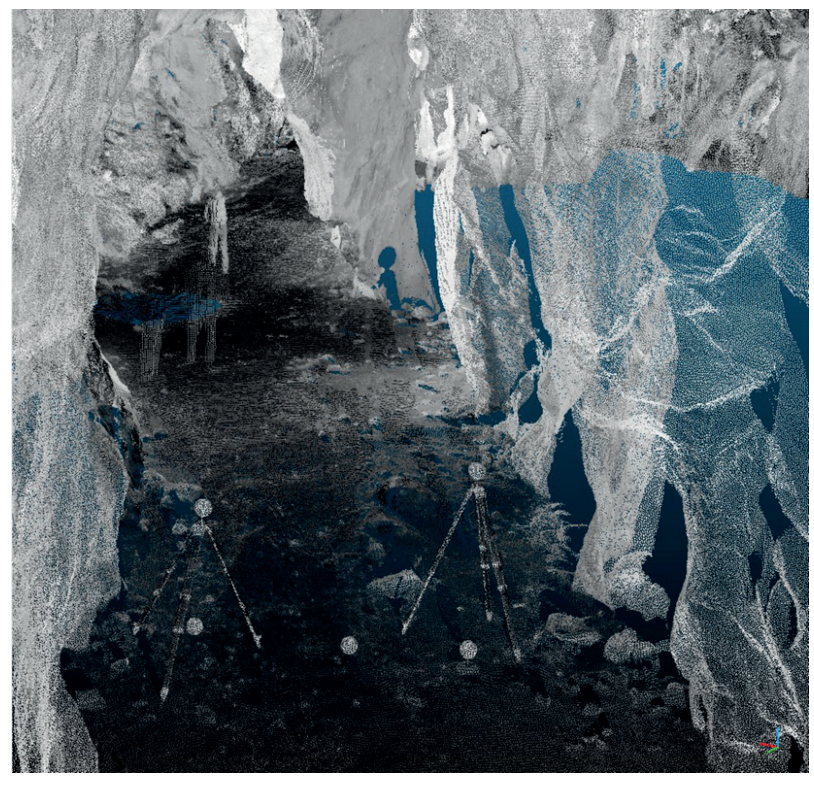

Fig. 8 Constructed point cloud that needs to be filtered from undesired objects

were down sampled to cca. 300000 points (Fig. 7) using CloudCompare processing software. The basic idea here was optimization and reduction of input data size due to significant hardware requirements and practical necessity of easier data manipulation in accordance to numerous scan stations. Additionally, the principal advantage of CloudCompare software is processing and 3D visualization of open and closed space that enable detailed inspection of point dataset and increasing signal to noise ratio.

At the same time constructed cloud dataset in the processing procedure were filtered using Interactive Segmentation Tool to remove undesired objects, i.e., persons, used instruments, accessories, etc. (Fig. 8). Interactive Segmentation Tool is user-defined tool, which use cloud dataset filtering in the iterative sequence. The surface 3D model of the Lower Cerovačke Cave based on cloud point dataset were constructed using Poisson surface reconstruction algorithm. This algorithm generated mesh model based on surface normal of the oriented cloud points. 
Here, constructed 3D surface model of the Lower Cerovačke Caves were used for speleological research that primarily involved detailed geodetic measurements and morphometry of the cave speleothems, whereas constructed 3D surface model were also used in 3D holographic illustrations. Besides, 3D modeled cave surface were initially used in morphometric and structural analyses because the centimeter-scale horizontal and vertical resolution allow very precise discontinuity delineation, statistic computation and accordingly, structure geometry definition. The principal advantage of the 3D modeled surface of the Lower Cerovačke Cave is its digital accessibility for any type of geological and paleontological investigation that might be performed in future.

\subsection{The Bizek quarry (Mt. Medvednica)}

The abandoned Bizek quarry on the Mt. Medvednica presents a suitable field laboratory for testing different spatial data acquisition techniques due to its accessibility and exposure of lithological and structural features. For numerous years it has been a training site for first year geology students learning the basics of outcrop measurement techniques of structural and sedimentological features. Digital models of the quarry can serve as a useful tool for complementing field data and further in depth study of geological outcrop features.

\subsubsection{Geological settings}

The Bizek quarry is located on the southwestern flanks of Mt. Medvednica. Mt. Medvednica forms one of several inselbergs located along the southern perimeter of Neogene Pannonian Basin. Its core exposes tectonic elements of the Adria plate consisting of Paleozoic to Triassic sedimentary and magmatic rocks which underwent Cretaceous metamorphism, Mesozoic carbonate and clastic sedimentary units, as well as a Jurassic ophiolitic mélange. The basic structure of Mt. Medvednica, like the rest of the Dinarides, formed during Cretaceous and Paleogene convergence and collision between elements of Europe and Africa, however, in the NW Dinarides this structural pattern of the basement is considerably complicated by younger lateral displacements and block rotations [38], and is largely covered by the Neogene sediments of the Pannonian Basin. In the Bizek area Upper Badenian deposits of the Pannonian Basin unconformably overlie basement rocks consisting largely of Upper Triassic dolomites (Fig. 9). The quarry exposes transgressive basal carbonate breccias, conglomerates and shallow

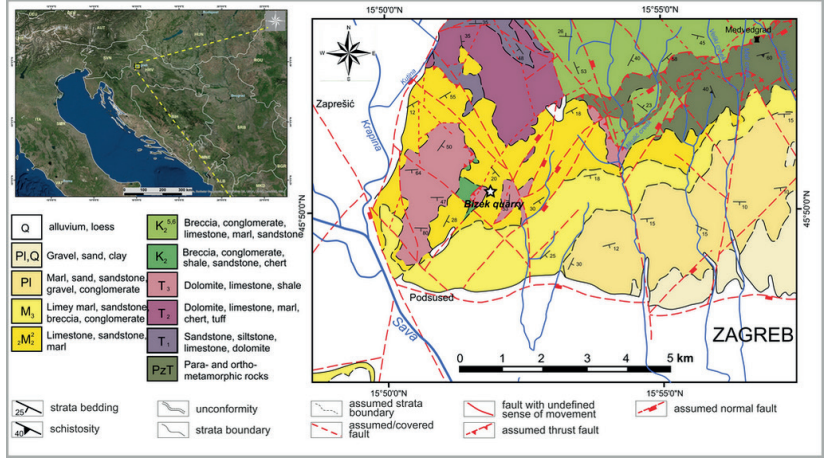

Fig. 9 Location of Bizek quarry on the SW part of Mt. Medvednica (index map in the left corner). The Bizek quarry is located within Upper Badenian deposits of the Pannonian Basin which uncomfortably overlie Upper Triassic dolomites

marine algal limestones that laterally and up section transition into fine grained clastics [39-41]. Although it has been abandoned for decades and vegetation has begun to infringe over a large part of the quarry floor, much of the strata is still clearly visible, especially on the steep walls of the old quarry cuts.

\subsubsection{Methodology and model building procedure}

During several data acquisition campaigns the entire quarry or its individual segments have been captured using both cameras mounted on UAS and by TLS. Analysis of the spatial data derived from the different techniques are very comparable, with differences on the level of 1-2 $\mathrm{cm}$ [42]. The use of a custom made multirotor UAS with onboard precise positioning and the ability to capture full frame high resolution Sony Alpha 7r 40 Mpx oblique images processed with modern photogrammetric software with implemented SFM algorithm (Pix4D version 4.0.18) of steep quarry walls has shown to be the most suitable approach for digital capture of larger geological objects. Although TLS can produce highly accurate results, data acquisition is much more labor intensive and there is always the uncertain availability of suitable and accessible scanning positions from which every surface of a large morphologically complex site can be captured.

Digital models of the Bizek quarry have proved their usefulness for inspection of both large and small features on inaccessible parts of quarry walls. Apart from the visual inspection alone, digital tools can be used to extract accurate measurements of structural features from the digital model, e.g., Fig. 10 shows bedding planes that are clearly identifiable on the digital quarry model. Using segmented line acquisition tools the exposures of the bedding planes can be traced and digitized on the surface of 


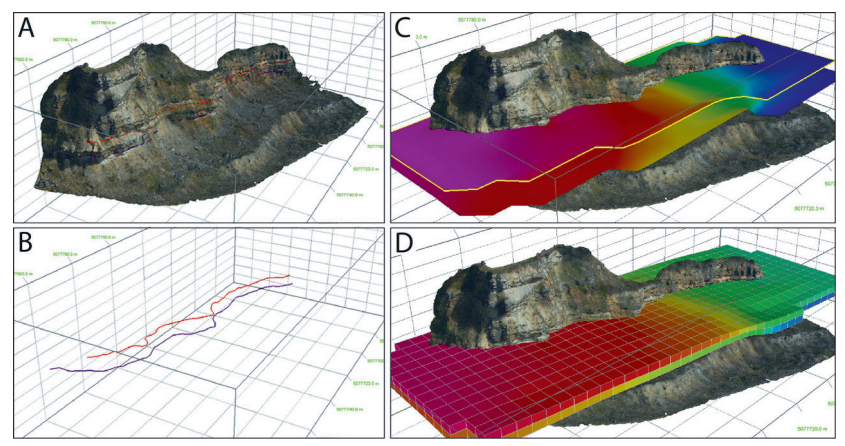

Fig. 10 a) Digital 3D model of Bizek quarry; b) Segmented line interpretation of subhorizontal strata in Badenian limestone; c) 3D model of top and bottom strata boundaries; d) Cellular model of Badenian limestone using strata properties e.g., porosity may be used for specified volumetric calculations

the quarry walls. Where the same planar surface is cut by quarry walls with changing orientation, the resultant digitized 3D line feature can be used to extract the 3D surface object of the bedding plane itself using interpolation. Similarly, this approach can be used to extract bedding and/or fault planes as is shown in Fig. 10. Such reconstruction is particularly useful for correlation of distinct surfaces whose exposures tend to be dislocated and visible only on individual parts of large segmented outcrops such as the Bizek quarry.

Furthermore, once extracted the surfaces can be used to delineate volumetric bodies for which cellular objects can be constructed and used for volume calculations and 3D modelling.

\subsection{The Solaris dinosaur tracksite (Istria)}

Fossil dinosaur footprints are important due to their high potential for deriving information regarding taxonomy, kinematics of motion, behavior, as well as the composition, density and distribution of extinct communities. Given that collection of physical samples during ichnological investigations is in most cases impractical and possibly destructive, studies of fossil tracksites have typically relied on direct observations and data collection performed in the field. However, digital data capture techniques have revolutionized the methods by which such studies can be carried out, introducing of a range of new tools for detailed examination, precise measurement, and communication of data. As an example, the study by [9] presented the practical aspects and advantages of digital model construction on the previously well-studied Solaris dinosaur tracksite in Istria, Croatia.

\subsubsection{Geological settings}

The Solaris tracksite is located within the naturist campsite 'Solaris' north of Poreč, in northwestern Istria (Fig. 11) and is of special significance due to the hundreds of preserved prints. The track-bearing bed is $30-35 \mathrm{~cm}$ thick and hosts a microfossil association including Nezzazatinella picardi, Cuneolina pavonia, and Neoiraqia insolita, pointing to a late Albian age [43]. It consists of a fossiliferous pelletal wackestone-mudstone displaying desiccation structures such as fenestral cavities and mud cracks, suggesting that the bed formed in a tidal flat environment [40]. It belongs to the thick sedimentary succession of the Adriatic Carbonate Platform (Fig. 11), which existed throughout much of the Mesozoic at the southern edge of the Neotethys Ocean [44]. During its long history, it experienced several phases of emersion that allowed proliferation of dinosaur communities. Unlike surrounding regions, the western part of the Istrian peninsula experienced only minor tectonic deformation during the major mountain building phase in the Dinarides.

\subsubsection{Methodology and model building procedure}

Field data from the Solaris site was collected using a terrestrial laser scanner FARO Focus 3D and digital SLR camera Nikon D3000 with a $24 \mathrm{~mm}$ fixed focal length lens. Georeferenced point cloud of site, derived by terrestrial laser scanning was performed with Faro Scene version 5.5, whereas image processing was processed using PixD version 4.0.18 software. Numerous theropod and sauropod footprints are uncovered on two separate outcrops, one of which was fully digitally captured with millimeter-scale resolution and high spatial accuracy, allowing both, outcrop scale mapping, as well as fine detail inspection and morphometric measurements at the level of individual

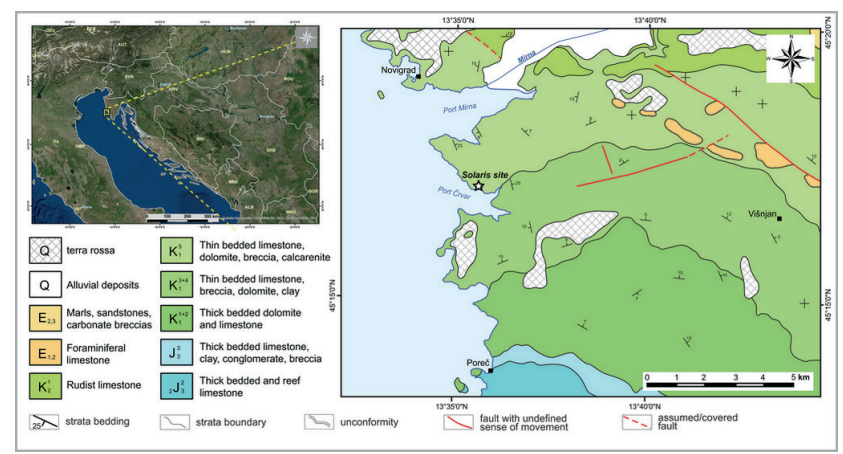

Fig. 11 Location of the Solaris dinosaur tracksite in NW Istria (index map in the left corner). The track-bearing bed is within late Albian carbonates deposited on the Mesozoic Adriatic Carbonate Platform 
footprints. It consists of a 33 by 13 meter heavily trampled bed surface with highly variable footprint preservation caused by the different physical characteristics of the original carbonate substrate (Fig. 12).

Overlay of the ichnological map published [45] with the digital data allowed for clear identification of all of the footprints recognized by the above authors during previous investigations of the site. Careful inspection of a DEM generated by photogrammetry and terrestrial laser scanning, visualized with an optimal setting of shaders and artificial lighting conditions, allowed the identification of previously unreported footprints during meticulous outcrop investigations performed in earlier studies of the site [45-47]. A total of 508 footprints comprising 32 trackways, 13 pairs, and 375 individual prints have been identified at the site by [45], while another 20 prints were identified by inspection of the digital model [9]. The average depth of the newly discovered prints was only $8 \mathrm{~mm}$ (the shallowest one being $4 \mathrm{~mm}$ ), and may explain why some of these prints were overlooked in previous studies, which relied on direct identification in the field. Evaluation of quantitative data acquisition from the digital model demonstrates that measurements are easily performed and are comparable to results derived using traditional methods. Comparison of measurements derived from the digital model and those reported by [45] showed that the results are very comparable, with only $1-2 \mathrm{~mm}$ average difference for length and width measurements.

The accuracy and detail of the data, as well as the ability of identifying new, previously undocumented footprints affirms that digital modelling can be effectively used for in depth ichnological analysis of relatively large fossil sites displaying prints with highly variable depths and preservation. Apart from serving as a research tool,

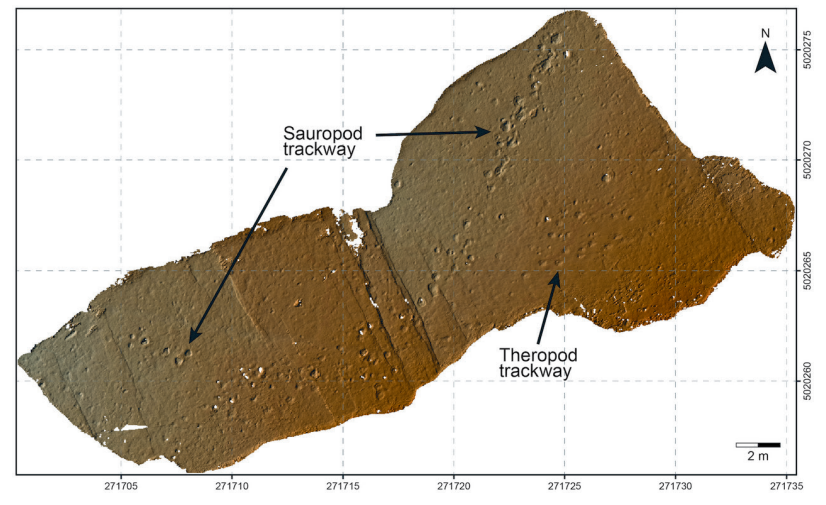

Fig. 12 Georeferenced digital elevation model of the Solaris tracksite derived from terrestrial laser scanning and photogrammetry data the digital model is a permanent quantitative record of an important iconological site, preserving its geoheritage for the future. This includes a detailed record of the holotype of the ichnospecies Titanosaurimanus nana (Fig. 13) introduced by [45]. This preservation aspect is especially important considering that the site is located in an area much frequented by tourists in summer months, most of whom are not aware of the site's presence, and can unintentionally cause damage to the exposed horizontal bed surface located at ground level. An extreme example is when cars were unwittingly parked on the site itself.

\subsection{The Duilovo flysch cliff (Split)}

Coastal areas are considered as one of the most endangered environments, being influenced by both, natural and anthropogenic processes. Coastal erosion is the most obvious problem when it comes to beaches and inhabited cliff areas. Understanding of the natural functioning of coasts is the prerequisite of a proper coastal management, as well as the accurate quantification of erosion rates. Increasing number of papers reporting on utility of TLS and digital photogrammetry for the coastal erosion monitoring is been published worldwide during the last decade $[20,27,48,49]$. This paper presents usefulness of both techniques used during the monitoring of erosion of the Duilovo sea cliff located in the Split urban area (Fig. 14).

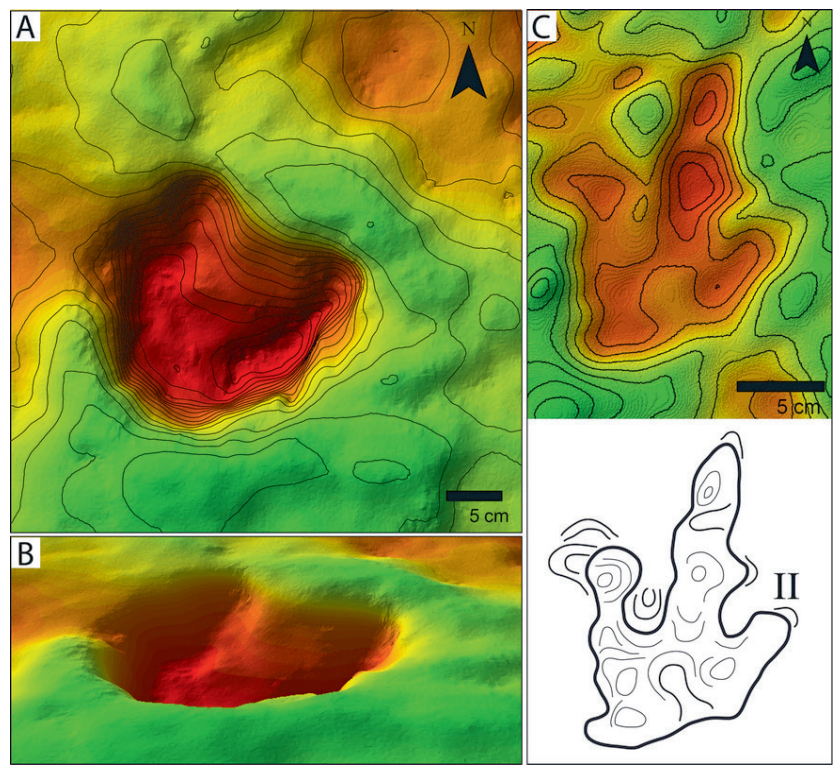

Fig. 13 Top-down (a) and oblique (b) views of digital model illustrating the footprint of the Titanosaurimanus nana ichnospecies introduced by [42]. Contour interval is $5 \mathrm{~mm}$. (c) High-resolution TIN model and interpretative sketch of a tridactyl footprint from the Solaris site. The position of the second digit II is indicated. Contour interval is $1 \mathrm{~mm}$ 


\subsubsection{Geological settings}

The Croatian coast is a long and steep primary coast, developed in partially submerged karstic relief. Development of the karst is associated to the thick carbonate succession of shallow-water carbonates which were deposited on the Adria microplate during the Mesozoic and Early Paleogene. Convergence of the Adria microplate and the stable Europe during Eocene-Oligocene resulted in cessation of shallow-water carbonate sedimentation and formation of sinorogenic flysch basins [44]. As the result, present day Croatian coast is dominated by carbonate lithology, while mechanically weaker rock assemblages (such as flysch and younger associated sediments, which from geotechnical aspect has moderate to low durability) [50], occupy minor segments. Due to the predominant carbonate fabric beaches are small and disperse, while true cliffs are rare and developed only in non-carbonate rocks [51,52]. One example of such cliffs, developed in Eocene flysch is retreating Duilovo cliff, situated in the Split urban area (Fig. 14).

\subsubsection{Methodology and model building procedure}

In order to quantify its erosion rates and to determine dominant erosional processes, a vegetation-free cliff-face of the Duilovo cliff is being monitored twice a year since 2012 by means of TLS Optech ILRIS-3D to produce 3D models. A series of point clouds were constructed and post-processed using Trimble RealWorks software. Georeferencing of obtained point clouds was done by measuring the position of stable objects visible on each cloud, using Trimble R8 GNSS receiver based on CROPOS VPPS virtual reference station real-time kinematic (VRS RTK) positioning service.

The preliminary results reported by [18] and [53] showed that cliff retreat rates vary between 3 and $18 \mathrm{~cm} / \mathrm{y}$, with extreme rates (up to $34 \mathrm{~cm} / \mathrm{y}$ ) on the subvertical part of the

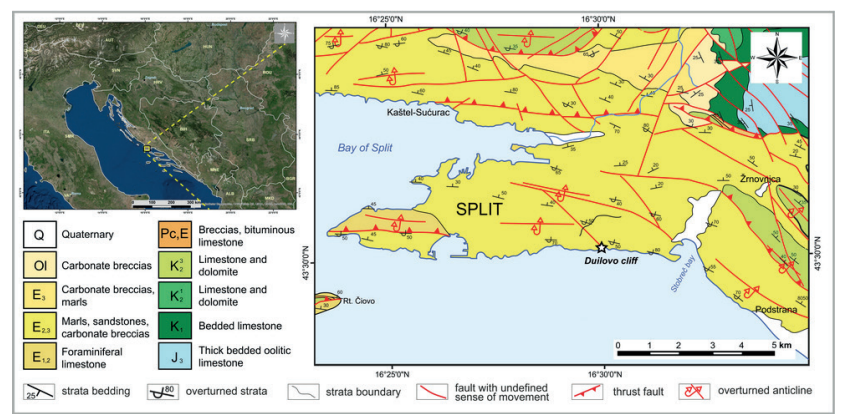

Fig. 14 Geological map of the Duilovo cliff in the Split urban zone. The cliff area is a part of the Split flysch basin, bordered by Cretaceous carbonates discordantly covered by Paleocene-Eocene "Liburnian deposits", and concordantly followed by the Eocene limestone and flysch deposits cliff (Fig. 15). Subaerial weathering of marly material is detected as the main reason of erosion, aided by gravitational processes and eventually wave erosion $[18,53]$.

The most western part of the cliff was additionally investigated in spring 2018. For this purposes, DJI Phantom 4 UAS equipped with a 20 MPX DJI FC6310 camera was used for rapid field campaign, in order to detect morphological changes on the cliff between and after two subsequent landslides. Image data processing is performed using photogrammetric software with implemented computer vision based SfM algorithm (Agisoft Photoscan version 1.4.3). The main result, after building image-based digital surface models (DSM) (Fig. 16) and the construction of DSMs of difference (DoDs), showed that landslide and rapid vegetation growth, both triggered by the heavy rains may act in opposite direction in terms of cliff slope stability.

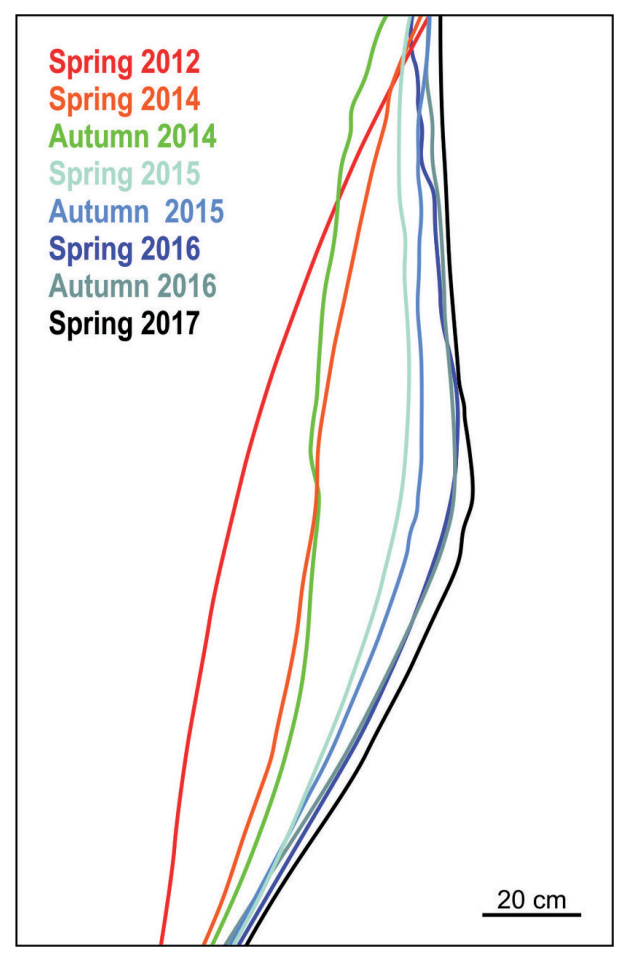

Fig. 15 Erosion rates on the subvertical segment of the cliff during the 5-year period

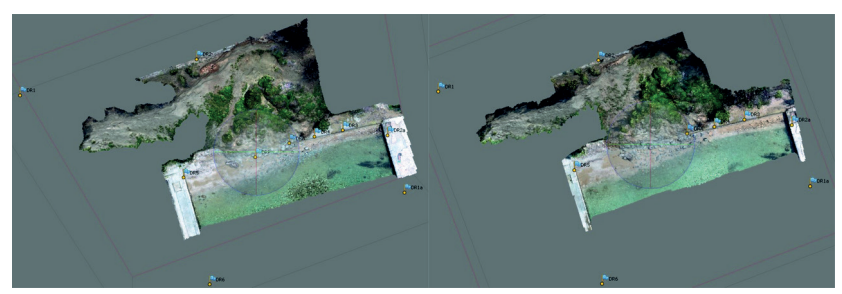

Fig. 16 Digital surface models of the cliff before (left) and after the landslide (right). Note the vegetation partially covered by the slided material and grown vegetation after the landslide (right) 


\section{Discussion and conclusions}

In the past decade, both TLS and UAS photogrammetry have become well established and tested methods in geological investigations [23, 27, 54-58]. The data which they are able to provide can be used to model outcrop features down to the minute millimeter scale as well as capture objects on the scale of tens to hundreds of meters, even kilometers across $[3,9]$. As a result, the term virtual outcrop has become common in research literature, which is used to describe a spatial data set derived by the integration of results from various digital data capture techniques, resulting in extremely detailed digital representations of real world geological outcrops [22]. The presented case studies demonstrate how the capabilities of these relatively new techniques can be successfully utilized in enhancing geological data gathering and analysis. The case studies are specific in that each one presents a geological object which carries with it special requirements with regards to observation conditions, accessibility and the scale of features being captured and analyzed.

Traditionally, many geological disciplines have relied heavily on interpretations and measurements which need be performed directly at the outcrop. This inherently carries with it certain difficulties, such as limited time available at a site, outcrop features inaccessible to measurement, as well as uncontrollable lighting and weather conditions which can hinder direct observation. Additionally, traditional tools used in such investigations are prone to certain limitations when it comes to acquisition of spatially accurate data. Detailed maps or sketches of outcrops are usually drawn with the aid of a hand-constructed quadratic grid and measuring tape which are effective but can easily result in deformation and inconsistencies in scale. Additionally, these tools are very time consuming, requiring lengthy field work. Standard photographs are another traditional method of documentation that can be also used for interpretation back at the office. However, they too are subject to inconsistencies in scale and suffer from a lack of depth perception needed for measurements in $3 \mathrm{D}$ space.

Although it may not fully replace direct field observations, introducing virtual outcrop analysis into the workflow offers certain advantages. Typical data acquisition usually requires only several hours of field work which is followed by several hours or days of data processing in the office depending on the scale of the project. Once constructed, a detailed spatially accurate digital 3D model allows the entire outcrop to be brought back to the office where all of its details can be repeatedly reexamined by multiple experts without the need for numerous lengthy trips to the physical outcrop itself. Full control over visualization conditions within the virtual environment such as adjustable viewing perspective, lighting, color, and contrast offers a considerable enhancement to the analysis process. This also includes close inspection of outcrop locations that might otherwise be physically difficult to reach (e.g. vertical cliff faces). Rapid and accurate spatial measurements and mapping, including volume calculations, can be easily performed within the digital 3D environment. Furthermore, the visualization potential of such data makes it an excellent educational and science popularization tool [59], while also being an effective method of documenting geological heritage sites, particularly those endangered by erosion or other forms of destruction [7].

Even though the type of output data derived from TLS and UAS photogrammetry is relatively similar, each approach carries with it certain advantages as well as limitations $[60,61]$. This is why both approaches have seen considerable development both in terms of advances in instrument and software technology, and practical application. Furthermore, while either TLS or photogrammetry can be used individually, approaches integrating multiple methods have been discussed and implemented by multiple authors [4, 54, 62-64].

In terms of consistency and accuracy TLS is a more robust method. However, with proper use, the resolution and accuracy of photogrammetric models can reach levels close to those acquired by TLS and satisfactory for many applications [61, 65-67]. Some of the advantages of photogrammetry are its low cost in terms of equipment and its ability to acquire more precise color information from the surface being captured. Another highly useful advantage of photogrammetry is the ability to use digitized historical photographs to recreate sites in their previous state for multi-temporal analysis [68], or even recreate those that have been completely destroyed $[69,70]$. In terms of operating distance modern TLS equipment has made great advances with abilities of capturing data at distances of up to several kilometers.

The case studies outlined in this contribution pinpoint some additional advantages of each method which are dependent on the specific features being studied and associated research objectives.

Spatial data acquisition of subterranean object represents challenging task and a detailed spatial information about caves is generally limited. Speleological objects are especially demanding for data acquisition due to technical 
limitation e.g., geodetic positioning, lack of accessibility, maneuvering space and natural light. In such specific environments, TLS has a certain advantage over photogrammetry since it is an active sensor that does not require ambient light in order to function.

The Lower Cerovačke Cave system was a pilot area for 3D modeling in Croatia where TLS method was first time applied to construct 3D holographic illustrations of underground object. Results show that innovative combined usage of geodetic positioning outside and within cave system with TLS may mitigate technical limitation e.g., geodetic positioning and provide sufficiently precise data that enable detailed geodetic measurements and morphometry of the cave objects. Using advanced Interactive Segmentation Tool constructed cloud dataset can be filtered of undesired objects; however, the filtering procedure should be performed with caution and in iterative steps due to possibility of removing useful data. Beside 3D holographic illustration of the Lower Cerovačke Cave surface the collected geodetic data were used in preliminary speleological morpho-structural analyses in order to compare observed cave discontinuities with mapped speleological features. Accordingly, digital accessibility of 3D modeled Lower Cerovačke Cave system clearly enables further structural analysis of recorded features and hence, provide basis for statistical analyses and modeling as well as any other type of geological and paleontological investigations.

The Bizek quarry is an example where digital techniques can be used for educational purposes and showcases their potential for sedimentological or structural studies. Following field work, students can visualize and reexamine their quantitative measurement data within a $3 \mathrm{D}$ virtual environment. The digital model enables them to have an overview of the entire quarry and see how their own measurements relate to the structural elements they identified in the field at discreet locations.

The Solaris case study demonstrates how integration of accurately georeferenced laser scans and photogrammetry is able to produce sub-millimeter resolution digital data with highly accurate geolocation and geometry which can be used for studying complex outcrop surfaces where minute morphological features need to be identified and mapped. Direct comparison of quantitative data derived from the digital model has confirmed that measurements may significantly improve results derived using traditional methods. The derived digital model represents a permanent document of an ichnologically significant tracksite appearance, enabling thus to preserve overexposed or endangered features as well as making them more accessible to a wider community of investigators who wish to study and compare its ichnological features down to the finest detail.

Understanding and documentation of a wide range of coastal processes operating on various scales is crucial for coastal defense and mitigation of hazardous effects in coastal areas. Remote coastal monitoring is widely used in coastal studies for decades. Until recently satellite images and aerial photography were usual methods used to cover large coastal areas [71], however, with the accuracy insufficient to describe processes occurring at scales less than $50 \mathrm{~cm}$, such as cliff erosion in case of the Duilovo cliff.

Furthermore, inaccessible coastal areas are demanding for surveying by means of classical geodetic methods. Geospatial data in such environments are, therefore, traditionally collected by classical aerial photogrammetry or using airborne laser scanning. However, the main disadvantage of both abovementioned methods is high cost of survey, allowing thus only infrequent sampling and the inadequate temporal coverage.

In order to quantify properly the erosion rates on the annual scale, data collection on the retreating Duilovo cliff requires sub-centimeter level of accuracy and at least twice a year filed campaign. Taking into account obtained high resolution data (Figs. 15 and 16) and the low frequency of handling the heavy equipment, the usage of TLS was estimated to be optimal for the long-term monitoring of the cliff erosion. However, when it comes to the highly episodic events such as landslides observed on the most-western part of the Duilovo cliff, the advantage is given to SfM photogrammetry. As stated by [48] and [52], affordable and easily transportable equipment used for UAS photogrammetry has a certain advantage, while keeping the accuracy and still producing high resolution spatial data.

Digital models of the different sections of the Duilovo cliff, either based on laser scanning technology or being photography-derived, showed that TLS and UAS might be interchangeable used in the same coastal environment, depending on the temporal and spatial requirements during coastal monitoring, as well as depending on processes that are being investigated.

As shown above, all four case studies demonstrated that TLS and UAS photogrammetry may considerably reduce survey time during geological studies and hereby total project costs. At the same time both methods provide high-resolution data sets that can be analyzed in a virtual environment from a sedimentological or structural aspect. Moreover, once acquired, these datasets are easily 
stored and could be easily used for the future multi-temporal spatial data comparison at any timeframe and scale, thus enhancing any target geological data gathering and analyses at the studied sites.

\section{Acknowledgement}

We would like to thank professor Loris Redovniković for his expert and technical support during field work and Robert Košćal for technical support during figure

\section{References}

[1] Hartzell, P., Glennie, C., Biber, K., Khan, S. "Application of multispectral LiDAR to automated virtual outcrop geology", ISPRS Journal of Photogrammetry and Remote Sensing, 88, pp. 147-155, 2014.

https://doi.org/10.1016/j.isprsjprs.2013.12.004

[2] Oskin, M. E., Arrowsmith, J. R., Corona, A. H., Elliott, A. J., Fletcher, J. M., Fielding, E. J., Gold, P. O., Gonzalez Garcia, J. J., Hudnut, K. W., Liu-Zeng, J., Teran, O. J. "Near-Field Deformation from the El Mayor - Cucapah Earthquake Revealed by Differential LIDAR", Science, 335(6069), pp. 702-705, 2012.

https://doi.org/10.1126/science.1213778

[3] Pringle, J. K., Brunt, R. L., Hodgson, D. M., Flint, S. S. "Capturing stratigraphic and sedimentological complexity from submarine channel complex outcrops to digital 3D models, Karoo Basin, South Africa", Petroleum Geoscience, 16(4), pp. 307-330, 2010. https://doi.org/10.1144/1354-079309-028

[4] Franceschi, M., Martinelli, M., Gislimberti, L., Rizzi, A., Massironi, M. "Integration of 3D modeling, aerial LiDAR and photogrammetry to study a synsedimentary structure in the Early Jurassic Calcari Grigi (Southern Alps, Italy)", European Journal of Remote Sensing, 48(1), pp. 527-539, 2015.

https://doi.org/10.5721/EuJRS20154830

[5] Svennevig, K., Guarnieri, P., Stemmerik, L. "From oblique photogrammetry to a 3D model - Structural modeling of Kilen, eastern North Greenland", Computers \& Geosciences, 83, pp. 120-126, 2015.

https://doi.org/10.1016/j.cageo.2015.07.008

[6] Bates, K. T., Manning, P. L., Vila, B., Hodgetts, D. "Threedimensional Modelling and Analysis of Dinosaur Trackways", Palaeontology, 51(4), pp. 999-1010, 2008.

https://doi.org/10.1111/j.1475-4983.2008.00789.x

[7] Bates, K. T., Rarity, F., Manning, P. L., Hodgetts, D., Vila, B., Oms, O., Galobart, À., Gawthorpe, R. L. "High-resolution LiDAR and photogrammetric survey of the Fumanya dinosaur tracksites (Catalonia): implications for the conservation and interpretation of geological heritage sites", Journal of the Geological Society, 165(1), pp. 115-127, 2008.

https://doi.org/10.1144/0016-76492007-033

[8] Chase, A. F., Chase, D. Z., Weishampel, J. F., Drake, J. B., Shrestha, R. L., Slatton, K. C., Awe, J. J., Carter, W. E. "Airborne LiDAR, archaeology, and the ancient Maya landscape at Caracol, Belize", Journal of Archaeological Science, 38(2), pp. 387-398, 2011. https://doi.org/10.1016/j.jas.2010.09.018 preparation. Student Cyndi Leneveu helped during part of the fieldwork and visual preparation of data. Students Petra Slavinić and Marko Erak assisted during data gathering and analysis. Midland Valley is acknowledged for providing an academic license for their software Move. We also would like to thank pilot Milivoj Hucaljuk for UAS mission planning support.

[9] Lužar-Oberiter, B., Kordić, B., Mezga, A. "Digital modelling of the late albian Solaris dinosaur tracksite (Istra, Croatia)", Palaios, 32(12), pp. 739-749, 2017.

https://doi.org/10.2110/palo.2017.034

[10] Sturzenegger, M., Stead, D. "Close-range terrestrial digital photogrammetry and terrestrial laser scanning for discontinuity characterization on rock cuts", Engineering Geology, 106(3-4), pp. 163-182, 2009.

https://doi.org/10.1016/j.enggeo.2009.03.004

[11] Amour, F., Mutti, M., Christ, N., Immenhauser, A., Benson, G. S., Agar, S. M., Tomas, S., Kabiri, L. "Outcrop analog for a oolitic carbonate ramp reservoir: a scale dependent geologic modeling approach based on stratigraphic hierarchy", AAPG Bulletin, 97(5), pp. 845-871, 2013.

https://doi.org/10.1306/10231212039

[12] Fanti, R., Gigli, G., Lombardi, L., Tapete, D., Canuti, P. "Terrestrial laser scanning for rockfall stability analysis in the cultural heritage site of Pitigliano (Italy)", Landslides, 10(4), pp. 409-420, 2013. https://doi.org/10.1007/s10346-012-0329-5

[13] Kuhn, D., Prüfer, S. "Coastal cliff monitoring and analysis of mass wasting processes with the application of terrestrial laser scanning: A case study of Rügen, Germany", Geomorphology, 213, pp. 153165, 2014.

https://doi.org/10.1016/j.geomorph.2014.01.005

[14] Vlastelica, G., Miščević, P., Fukuoka, H. "Monitoring of vertical cuts in soft rock mass, defining erosion rates and modelling time-dependent geometrical development of the slope", In: Rock Mechanics and Rock Engineering: From the Past to the Future, Taylor \& Francis Group, London, United Kingdom, 2016, pp. 1249-1254. [online] Available at: https://bib.irb.hr/datoteka/832017.ch202.pdf [Accessed: 17 May 2019]

[15] Tavani, S., Granado, P., Corradetti, A., Girundo, M., Iannance, A., Arbués, P., Muñoz, J. A., Mazzoli, S. "Building a virtual outcrop, extracting geological information from it, and sharing the results in Google Earth via OpenPlot and Photoscan: An example from the Khaviz Anticline (Iran)", Computers \& Geosciences, 63, pp. 44-53, 2014.

https://doi.org/10.1016/j.cageo.2013.10.013

[16] Matoš, B., Zajc, M., Kordić, B., Tomljenović, B., Gosar, A. "Quaternary fault activity in the SW Pannonian Basin: GPR surveying in Bilogora (NE Croatia)", Geological Quarterly, 61(1), pp. 19-38, 2017.

https://doi.org/10.7306/gq.1308 
[17] Banak, A., Pikelj, K., Lužar-Oberiter, B., Kordić, B. "Characteristics of Pleistocene aeolian - alluvial sediments of the northern coastal cliff of Vrgada island (Adriatic Sea, Croatia)", presented at 4th Coastal and Maritime Mediterranean Conference, Split, Croatia, Nov. 29-Dec. 1, 2017.

https://doi.org/10.5150/cmcm.2017.004

[18] Vlastelica, G., Pikelj, K., Kordić, B. "Erosional processes acting on coastal cliffs in the Split urban zone, Croatia", presented at 4th Coastal and Maritime Mediterranean Conference, Split, Croatia, Nov. 29-Dec. 1, 2017.

https://doi.org/10.5150/cmcm.2017.015

[19] Sečanj, M., Arbanas, S. M., Kordić, B., Krkač, M., Gazibara, S. B. "Identification of Rock Fall Prone Areas on the Steep Slopes Above the Town of Omiš, Croatia", In: Mikoš, M., Vilímek, V., Yin, Y., Sassa, K. (eds.) Advancing Culture of Living with Landslides, WLF 2017, Springer, Cham, Switzerland, 2017, pp. 481-487.

https://doi.org/10.1007/978-3-319-53483-1_57

[20] Pikelj, K., Ružić, I., Ilić, S., James, M. R., Kordić, B. "Implementing an efficient beach erosion monitoring system for coastal management in Croatia", Ocean \& Coastal Management, 156, pp. $223-238,2018$.

https://doi.org/10.1016/j.ocecoaman.2017.11.019

[21] Vlastelica, G., Miščević, P., Štambuk Cvitanović, N., Glibota, A. "Geomechanical aspects of remediation of quarries in the flysch: case study of abandoned quarry in Majdan, Croatia", In: Litvinenko, V. (ed.) Geomechanics and Geodynamics of Rock Masses - Selected Papers from the 2018. European Rock Mechanics Symposium, 1st ed., CRC Press, London, UK, 2018, pp. 679-684. https://doi.org/10.1201/9780429449222

[22] Xu, X., Aiken, C. L. V., Bhattacharya, J. P., Corbenau, R. M., Nielsen, K. C., McMechan, G. A., Abdelsalam, M. G. "Creating virtual 3-D outcrop", The Leading Edge, 19(2), pp. 113-224, 2000. https://doi.org/10.1190/1.1438576

[23] Rarity, F., Van Lanen, X. M. T., Hodgetts, D., Gawthorpe, R. L., Wilson, P., Fabuel-Perez, I., Redfern, J. "LiDAR-based digital outcrops for sedimentological analysis: workflows and techniques", In: Martinius, A. W., Howell, J. A., Good, T. R. (eds.) Sediment-Body Geometry and Heterogeneity: Analogue Studies for Modelling the Subsurface, Geological Society, London, UK, 2014, pp. 153-183. https://doi.org/10.1144/SP387.5

[24] Kurz, T. H., Buckley, S. J., Howell, J. A. "Close Range Hyperspectral Imaging Integrated with Terrestrial LIDAR Scanning Applied to Rock Characterisation at Centimetre Scale", In: Proceedings of the International Archives of the Photogrammetry, Remote Sensing and Spatial Information Sciences, XXII ISPRS Congress, Melbourne, Australia, 2012, pp. 417-422.

https://doi.org/10.5194/isprsarchives-XXXIX-B5-417-2012

[25] Gordon, S., Lichti, D., Steward, M. "Application of a HighResolution, Ground-Based Laser Scanner for Deformation Measurements", In: Proceedings of the 10th FIG International Symposium on Deformation Measurements, Orange, California, USA, 2001, pp. 23-32. [online] Available at: https://www.fig.net/ resources/proceedings/2001/2001_comm6_orange.htm [Accessed: 23 May 2019]
[26] Balis, V., Karamitsos, S., Kotsis, I., Liapakis, C., Simpas, N. "3D-Laser Scanning: Integration of Point Cloud and CCD Camera Video Data for the Production of High Resolution and Precision RGB Textured Models: Archaeological Monuments Surveying Application in Ancient Ilida", presented at the FIG Working Week 2004, Athens, Greece, May, 22-27, 2004. [online] Available at: https://fig.net/resources/proceedings/fig_proceedings/athens/ papers/wsa2/WSA2_5_Balis_et_al.pdf [Accessed: 26 May 2019]

[27] Colomina, I., Molina, P. "Unmanned aerial Systems for photogrammetry and remote sensing: A review", ISPRS Journal of Photogrammetry and Remote Sensing, 92, pp. 79-97, 2014. https://doi.org/10.1016/j.isprsjprs.2014.02.013

[28] Westoby, M. J., Brasington, J., Glasser, N. F., Hambrey, M. J., Reynolds, J. M. "Structure-from-Motion' photogrammetry: A lowcost, effective tool for geoscience applications", Geomorphology, 179, pp. 300-314, 2012.

https://doi.org/10.1016/j.geomorph.2012.08.021

[29] Malez, M. "Cerovačke pećine - najveće u Hrvatskoj" (Cerovačke Caves - the largest in Croatia), Priroda, 45(6), pp. 201-208, 1957. (in Croatian)

[30] Malez, M. "Cerovačke pećine" (Cerovačke Caves), Speleološko društvo Hrvatske, 1, pp. 1-44, 1965. (in Croatian)

[31] Kolak, T. "Donja Cerovačka špilja" (Lower Cerovačka Cave), Hrvatski arheološki godišnjak, 6, pp. 503-504, 2010. (in Croatian)

[32] Bočić, N., Ris, N. "Novija speleološka istraživanja u Cerovačkim špiljama" (The latest speleological investigations in Cerovačke Caves- in Croatian), presented at Skup speleologa Hrvatske, Ogulin, Croatia, Nov, 20-22, 2015. [online] Available at: http://speleologija. eu/repozitorij/publikacije/Skup\%202015\%20Ogulin\%20-\%20 knjiga\%20sazetaka.pdf [Accessed: 13 March 2019] (in Croatian)

[33] Ivanović, A., Sokač, K., Marković, S., Sokač, B., Šušnjar, M., Nikler, L., Šušnjar, A. "Osnovna geološka karta SFRJ 1:100000, List Obrovac, L33-140" (Basic Geological Map of SFRY 1:100000, Obrovac sheet), Institut za Geološka Istraživanja, Zagreb, Savezni Geološki Zavod, Beograd, Serbia, 1973. (in Croatian)

[34] Šušnjar, M., Sokač, B., Bahun, S., Bukovac, J., Nikler, L., Ivanović, A. "Osnovna geološka karta SFRJ 1: 100 000, List Udbina, L33128" (Basic Geological Map of SFRY 1:100000, Udbina sheet), Institut za Geološka Istraživanja, Zagreb, Savezni Geološki Zavod, Beograd, Serbia, 1973. (in Croatian)

[35] Vlahovic, I., Mandic, O., Mrinjek, E., Bergant, S., Cosovoc, V., De Leeuw, A., Enos, P., Hrvatovic, H., Maticec, D., Miksa, G., Nemec, W., Pavelic, D., Pencinger, V., Velic, I., Vranjkovic, A. "Marine to continental depositional systems of Outer Dinarides foreland and intra-montane basins (Eocene-Miocene, Croatia and Bosnia and Herzegovina)", Journal of Alpine Geology, 54, pp. 405470, 2012. [online] Available at: https://pdfs.semanticscholar.org/ ae34/ab7c31c6bbb576b6adb5a0038b17624f8ff7.pdf [Accessed: 22 May 2019]

[36] Velić, I., Velić, J., Vlahović, I., Cvetković, M. "Geološki vodič kroz NP Paklenica" (Geological Guide trough NP Paklenica), Paklenica National Park, Starigrad, Croatia, 2014. (in Croatian)

[37] Pavasović, M., Marjanović, M., Bašić, T. "Towards the new Croatian terrestrial reference frame based on CROPOS - preliminary results", Technical Gazette, 23(3), pp. 893-897, 2016. https://doi.org/10.17559/TV-20141114153027 
[38] Tomljenović, B., Csontos, L., Márton, E., Márton, P. "Tectonic evolution of northwestern Internal Dinarides as constrained by structures and rotation of Medvednica Mountains, North Croatia", Geological Society, London, Special Publications, 298, pp. 145-167, 2008. https://doi.org/10.1144/SP298.8

[39] Vrsaljko, D., Pavelić, D., Miknić, M., Brkić, M., Kovačić, M., Hećimović, I., Hajek-Tadesse, V., Avanić, R., Kurtanjek, N. "Middle Miocene (Upper Badenian/Sarmatian) Palaeoecology and Evolution of the Environments in the Area of Medvednica Mt. (North Croatia)", Geologia Croatica, 59(1), pp. 51-63, 2006. [online] Available at: https://hrcak.srce.hr/10309 [Accessed: 15 May 2019]

[40] Vrsaljko, D., Pavelić, D., Bajraktarević, Z. "Stratigraphy and Palaeogeography of Miocene Deposits from the Marginal Area of Žumberak Mt. and the Samoborsko Gorje Mts. (Northwestern Croatia)", Geologia Croatica, 58(2), pp. 133-150, 2005. [online] Available at: https://hrcak.srce.hr/3652 [Accessed: 16 May 2019]

[41] Basso, D., Vrsaljko, D., Grgasović, T. "The coralline flora of a Miocene maërl: the Croatian Litavac", Geologia Croatica, 61(2-3), pp. 333-340, 2008. [online] Available at: https://hrcak.srce.hr/30672 [Accessed: 16 April 2019]

[42] Slavinić, P. "Usporedba podataka laserskog skeniranja i fotogrametrije na primjeru kamenoloma Bizek" (Comparison of laser scanning and photogrammetric data in the case of the quarry Bizek), MSc Thesis, University of Zagreb, 2016. (in Croatian)

[43] Tunis, G., Venturini, S. "New Dinosaur track sites in the Albian (Early Cretaceous) of the Istrian peninsula (Croatia) - Part I - Stratigraphy and Sedimentology", Memorie di Scienze Geologiche, 52(2), pp. 195-226, 2000. [online] Available at: http:/www.fondazionemcr.it/ UploadDocs/13425_mem_sci_geol_vol52_2_pagg195_226.pdf [Accessed: 16 April 2019]

[44] Vlahović, I., Tišljar, J., Velić, I., Matičec, D. "Evolution of the Adriatic Carbonate Platform: Palaeogeography, main events and depositional dynamics", Palaeogeography, Palaeoclimatology, Palaeoecology, 220(3-4), pp. 333-360, 2005. https://doi.org/10.1016/j.palaeo.2005.01.011

[45] Dalla Vecchia, F. M., Tarlao, A. "New dinosaur track sites in the Albian (Early Cretaceous) of the Istrian Peninsula (Croatia), Part II - Paleontology", Memorie di Scienze Geologiche, 52(2), pp. 227-292, 2000. [online] Available at: http://www.fondazionemcr.it/ UploadDocs/13426_mem_sci_geol_vol52_2_pagg227_292.pdf [Accessed: 16 April 2019]

[46] Dalla Vecchia, F. M. "Lo studio del sito cretacico con impronte di dinosauro di Cervera/Cervar (Punta del Dente, Istria)" (The study of the Cretaceous site with dinosaur footprints of Cervera / Cervar (Punta del Dente, Istria)), Natura Nascosta, 13, pp. 24-33, 1996. (in Italian)

[47] Dalla Vecchia, F. M. "Theropod footprints in the Cretaceous Adriatic-Dinaridic carbonate platform (Italy and Croatia)", Gaia, 15, pp. 355-367, 1998.

[48] Gonçalves, J. A., Henriques, R. "UAV photogrammetry for topographic monitoring of coastal areas", ISPRS Journal of Photogrammetry and Remote Sensing, 104, pp. 101-111, 2015. https://doi.org/10.1016/j.isprsjprs.2015.02.009
[49] Kim, H., Lee, S. B., Min, K. S. "Shoreline Change Analysis using Airborne LiDAR Bathymetry for Coastal Monitoring", In: Lee, J. L., Griffiths, T., Lotan, A., Suh, K.-S., Lee, J. (eds.) The 2nd International Water Safety Symposium, Journal of Coastal Research, Special Issue, 79, pp. 269-273, 2017. https://doi.org/10.2112/SI79-055.1

[50] Vlastelica, G., Miščević, P., Štambuk Cvitanović, N. "Durability of soft rocks in Eocene flysch formation (Dalmatia, Croatia)", Engineering Geology, 245, pp. 207-217, 2018.

https://doi.org/10.1016/j.enggeo.2018.08.015

[51] Pikelj, K., Juračić, M. "Eastern Adriatic Coast (EAC): Geomorphology and Coastal Vulnerability of a Karstic Coast", Journal of Coastal Research, 29(4), pp. 944-957, 2013. https://doi.org/10.2112/JCOASTRES-D-12-00136.1

[52] Pikelj, K., Dragnić, V., Malovrazić, N. "Eastern Adriatic: Slovenia, Croatia and Montenegro", In: Pranzini, E., Williams, A. (eds.) Coastal Erosion and Protection in Europe, Routledge, Oxford, UK, 2013, pp. 324-344.

https://doi.org/10.4324/9780203128558

[53] Pikelj, K., Vlastelica, G., Kordić, B. "Evaluation of erosional processes of the eroding flysch cliff in the Split urban zone (Croatia)", In: Benincasa, F. (ed.) 7th International Symposium: Monitoring of Mediterranean Coastal Areas: Problems and Measurement Techniques Proceedings and Report - Italy 2018, Firenze University Press, Florence, Italy, 2018, pp. 607-616.

[54] Breithaupt, B. H., Matthews, N. A., Noble, T. A. "An Integrated Approach to Three-Dimensional Data Collection at Dinosaur Tracksites in the Rocky Mountain West", Ichnos, 11(1-2), pp. 11-26, 2004. https://doi.org/10.1080/10420940490442296

[55] Bellian, J. A., Kerans, C., Jennette, D. C. "Digital Outcrop Models: Applications of Terrestrial Scanning Lidar Technology in Stratigraphic Modeling", Journal of Sedimentary Research, 75(2), pp. 166-176, 2005. https://doi.org/10.2110/jsr.2005.013

[56] Pringle, J. K., Howell, J. A., Hodgetts, D., Westerman, A. R., Hodgson, D. M. "Virtual outcrop models of petroleum reservoir analogues: a review of the current state-of-the-art", First Break, 24(3), pp. 33-42, 2006. https://doi.org/10.3997/1365-2397.2006005

[57] Buckley, S. J., Howell, J. A., Enge, H. D., Kurz, T. H. "Terrestrial laser scanning in geology: data acquisition, processing and accuracy considerations", Journal of the Geological Society, 165(3), pp. 625-638, 2008. https://doi.org/10.1144/0016-76492007-100

[58] Mallison, H., Wings, O. "Photogrammetry in Paleontology - a Practical Guide", Journal of Paleontological Techniques, 12, pp. 1-31, 2014. [online] Available at: https://www.jpaleontologicaltechniques. org/pasta3/JPT\%20N12/Bulletin.html [Accessed: 20 April 2019]

[59] Pringle, J. K. "Educational egaming: the future for geoscience virtual learners?", Geology Today, 30(4), pp. 147-150, 2014. https://doi.org/10.1111/gto.12058 
[60] Chandler, J., Buckley, S. "Structure from motion (SfM) photogrammetry vs terrestrial laser scanning", In: Carpenter, M. B., Keane, C. M. (eds.) Geoscience Handbook, 5th ed, American Geosciences Institute, Alexandria, VA, USA, 2016. [online] Available at: https:// figshare.com/articles/Structure_from_motion_SFM_photogrammetry_vs_terrestrial_laser_scanning/9457565/1 [Accessed: 8 May 2019]

[61] Wilkinson, M. W., Jones, R. R., Woods, C. E., Gilment, S. R., McCaffrey, K. J. W., Kokkalas, S., Long, J. J. "A comparison of terrestrial laser scanning and structure-from-motion photogrammetry as methods for digital outcrop acquisition", Geosphere, 12(6), pp. 1865-1880, 2016. https://doi.org/10.1130/GES01342.1

[62] Sima, A., Buckley, S. J., Schneider, D., Howell, J. A. "An improved workflow for image- and laser-based virtual geological outcrop modelling", In: Paparoditis, N., Pierrot-Deseilligny, M., Mallet, C., Tournaire, O. (eds.) IAPRS, Vol. XXXVIII, Part 3B, SaintMandé, France, 2010, pp. 115-120. [online] Available at: http:// www.riegl.com/uploads/tx_pxpriegldownloads/Sima_isprs2010.pdf [Accessed: 14 April 2019]

[63] Remondino, F., Rizzi, A., Girardi, S., Petti, F. M., Avanzini, M. "3D Ichnology - recovering digital 3D models of dinosaur footprints", The Photogrammetric Record, 25(131), pp. 266-282, 2010. https://doi.org/10.1111/j.1477-9730.2010.00587.x

[64] Romilio, A., Hacker, J. M., Zlot, R., Poropat, G., Bosse, M., Salisbury, S. W. "A multidisciplinary approach to digital mapping of dinosaurian tracksites in the Lower Cretaceous (ValanginianBarremian) Broome Sandstone of the Dampier Peninsula, Western Australia", PeerJ, 5, 2013. https://doi.org/10.7717/peerj.3013

[65] Favalli, M., Fornaciali, A., Isola, I., Tarquini, S., Nannipieri, L. "Multiview 3D reconstruction in geosciences", Computers \& Geosciences, 44, pp. 168-176, 2012. https://doi.org/10.1016/j.cageo.2011.09.012
[66] Thoeni, K., Giacomini, A., Murtagh, R., Kniest, E. "A comparison of multi-view 3D reconstruction of a rock wall using several cameras and a laser scanner", The International Archives of the Photogrammetry, Remote Sensing and Spatial Information Sciences, XL-5, pp. 573-580, 2014. https://doi.org/10.5194/isprsarchives-XL-5-573-2014

[67] Nouwakpo, S. K., Weltz, M. A., McGwire, K. "Assessing the performance of structure from-motion photogrammetry and terrestrial LiDAR for reconstructing soil surface microtopography of naturally vegetated plots", Earth Surface Processes and Landforms, 41(3), pp. 308-322, 2016. https://doi.org/10.1002/esp.3787

[68] Baldi, P., Fabris, M., Marsella, M., Monticelli, R. "Monitoring the morphological evolution of the Sciara del Fuoco during the 20022003 Stromboli eruption using multi-temporal photogrammetry", ISPRS Journal of Photogrammetry and Remote Sensing, 59(4), pp. 199-211, 2005. https://doi.org/10.1016/j.isprsjprs.2005.02.004

[69] Falkingham, P. L., Bates, K. T., Farlow, J. O. "Historical Photogrammetry: Bird's Paluxy River Dinosaur Chase Sequence Digitally Reconstructed as It Was prior to Excavation 70 Years Ago", PLOS ONE, 9(4), Article ID: e93247, 2014. https://doi.org/10.1371/journal.pone.0093247

[70] Lallensack, J. N., Sander, P. M., Knötschke, N., Wings, O. "Dinosaur tracks from the Langenberg Quarry (Late Jurassic, Germany) reconstructed with historical photogrammetry: evidence for large theropods soon after insular dwarfism", Palaeontologia Electronica, Article ID: 8.2.31A, 2015. [online] Available at: https://palaeo-electronica.org/content/pdfs/529.pdf [Accessed: 28 April 2019.]

[71] Dekker, A. G., Brando, V. E., Anstee, J. M., Pinnel, N., Kutser, T., Hoogenboom, E. J., Peters, S., Pasterkamp, R., Vos, R., Olbert, C., Malthus, T. J. M. "Imaging Spectrometry of Water", In: Van der Meer, F. D., De Jong, S. M. (eds.) Imaging Spectrometry: Basic principles and prospective applications. Springer, Dordrecht, The Netherlands, 2001, pp. 307-359. https://doi.org/10.1007/978-0-306-47578-8_11 